\title{
Determinan Faktor Yang Memengaruhi Disloyalitas Nasabah Bank Pembiayaan Rakyat Syariah
}

\author{
Muhammad Hasan Muzaki \\ Ilmu Ekonomi-Fakultas Ekonomi UNESA \\ Email: muhammadmuzaki@mhs.unesa.ac.id \\ Ahmad Ajib Ridlwan \\ Ilmu Ekonomi-Fakultas Ekonomi UNESA \\ Email:ahmadajibridlwan@unesa.ac.id
}

\begin{abstract}
Abstrak:
The decline customer occurs in the PT. BPR syariah Lantabur Tebuireng which includes at the 5 rank of BPRS national category of good financial performance with the assets of Rp 100 billion - under to. 250 billion. This research purpose to identify the factors which affects disloyalty of syariah banking customer through case study of BPRS lantabur Tebuireng customer in Prajurit Kulon Market. This research uses 54 respondents samples as the disloyal customer from BPR Syariah Lantabur Tebuireng in Prajurit Kulon Market. The technique of data collection uses questionnaire. Technique of validity uses method of Bartlett Test of Spericity. Reability test uses Measure method of Sampling Adequency (MSA) Kaiser Matter Olkin also data analysis uses factor analysis with analysis instrument in the form of SPSS 22. The results of research shows that the factor which disloyalty affects Syariah banking customer consists of three factors. Those are ethic of business (Performance enhancement, technology benefits, innovation, and value benefits also position exploitation, disintegrate of information and serving inconvenience), customer satisfaction (business ethic of Islam, price, social convenience and demography), also religiosity.

[Peristiwa penurunan jumlah nasabah terjadi pada PT. BPR Syariah Lantabur Tebuireng yang merupakan BPRS dengan peringkat ke-5 skala nasional kategori BPRS berkinerja keuangan sangat bagus dengan Aset Rp. 100 miliar - di bawah Rp. 250 miliar. Penelitian ini bertujuan untuk mengetahui faktor-faktor yang memengaruhi disloyalitas nasabah perbankan syariah dengan studi kasus pada nasabah BPRS Lantabur Tebuireng di Pasar Prajurit Kulon. Penelitian ini menggunakan sampel sebanyak 54 responden yang merupakan nasabah disloyal dari BPR Syariah Lantabur Tebuireng di Pasar Prajurit Kulon. Teknik pengumpulan data menggunakan kuisioner. Teknik validitas menggunakan metode Bartlett Test of Spericity dan pengujian Realibilitas menggunakan metode Measure of Sampling Adequency (MSA) Kaiser Meyyer Olkin, serta analisis data menggunakan analisis faktor dengan alat analisis berupa SPSS 22. Hasil Penelitian menunjukkan bahwa faktor yang memengaruhi disloyalitas nasabah perbankan syariah terdiri atas tiga faktor. Faktor tersebut adalah etika bisnis (peningkatan kinerja, pemanfaatan teknologi, inovasi dan nilai manfaat serta eksploitasi jabatan, disintegrasi informasi, dan ketidaknyamanan layanan), kepuasan nasabah (etika bisnis islam, harga, kenyamanan sosial dan demografi), serta religiusitas.]
\end{abstract}

Kata Kunci: Disloyalitas; Bank Pembiayaan Rakyat Syariah; Etika Bisnis; Kepuasan Nasabah; Religiusitas. 


\section{PENDAHULUAN}

Industri keuangan syariah mengalami pertumbuhan sebesar $26,97 \%$ selama lima tahun terakhir dengan total aset perbankan syariah sebesar Rp. 435,02 triliun. Indusitri keuangan syariah terbagi atas empat sektor utama: Perbankan yang terdiri atas Bank Umum Syariah (BUS), Unit Usaha Syariah dan Bank Pembiayaan Rakyat Syariah (BPRS); NonPerbankan yang terdiri atas koperasi syariah/BMT, Perusahaan takaful (retakaful), perusahaan pembiayaan syariah, dana pensiun syariah dan penggadaian syariah; Pasar modal dan pasar uang yang terdiri atas sukuk, reksadana syariah, dan saham syariah; serta dana sosial keagamaan yang terdiri atas dana haji, zakat, dan wakaf. Perkembangan tersebut diiringi peningkatan kesadaran masyarakat terhadap keuangan syariah. ${ }^{1}$

Rencana pengembangan perbankan syariah telah ditetapkan dalam Roadmap Perbankan Syariah Indonesia pada periode 2015-2019. Peran perbankan syariah secara nasional selain menciptakan pertumbuhan ekonomi yang berkelanjutan, meratakan pembangunan dan membuat stabilitas sistem keuangan serta berdaya saing. Roadmap memuat isu strategis yang menjadi pertimbangan mengenai pemahaman dan kesadaran masyarakat terhadap perbankan syariah serta produk dan layanan yang harus menyesuaikan harapan atau ekspektasi dari masyarakat Indonesia. ${ }^{2}$

Sehingga persebaran perbankan untuk memperluas akses terhadap produk dan layanan di seluruh wilayah Indonesia perlu dilakukan. BPRS yang merupakan sektor perbankan syariah skala mikro dengan Dana Pihak Ketiga (DPK) terkecil dalam sektor perbankan syariah perlu melakukan upaya mempertahankan dan meningkatkan DPK. Akumulasi DPK untuk sektor perbankan syariah sebagai berikut:

Tabel 1.

Akumulasi Dana Pihak Ketiga Perbankan Syariah

Tahun 2016-2018

\begin{tabular}{llll}
\hline \multirow{2}{*}{$\begin{array}{c}\text { Sektor } \\
\text { Perbankan }\end{array}$} & \multicolumn{3}{c}{$\begin{array}{c}\text { Akumulasi DPK dalam Miliar } \\
\text { Rupiah* }\end{array}$} \\
\cline { 2 - 4 } & $\mathbf{2 0 1 6}$ & $\mathbf{2 0 1 7}$ & $\mathbf{2 0 1 8}$ \\
\hline BUS & 206.407 & 238.393 & 240.59 \\
& & & 6 \\
UUS & 72.928 & 96.495 & 98.599 \\
BPRS & 5.823 & 6.987 & 7.485 \\
\hline
\end{tabular}

Melalui tabel di atas dapat diketahui bahwa terjadi peningkatan jumlah DPK pada setiap sektor perbankan syariah. Namun, perolehan DPK terkecil adalah BPRS. Dengan demikian, Peningkatan kualitas layanan dan produk perlu dilakukan untuk mempertahankan dan meningkatkan DPK, serta menghindari penurunan nasabah atau disloyalitas nasabah yang berakibat pada penurunan DPK. Hal ini sesuai dengan penelitian yang dilakukan oleh Munandar, ${ }^{4}$ yang menyatakan bahwa perusahaan kehilangan $10-30 \%$ pelanggan setiap tahunnya tanpa diketahui penyebabnya secara pasti dan kapan terjadi serta siapa saja yang

\footnotetext{
1 Otoritas Jasa Keuangan, Laporan Perkembangan Keuangan Syariah Indonesia, Jakarta: Otoritas Jasa Keuangan, 2017, vi.

2 Ibid., viii.

${ }^{3}$ Data olahan SPS Juli 2018

${ }^{4}$ Munandar, Relationship Marketing, Yogyakarta: Ekuilibria, 2016, 77.
} 
menghilang. Perusahaan baru menyadari ketika laba terus menurun. Solusi untuk mengatasi persoalan tersebut, perusahaan berusaha mencari pelanggan baru untuk mengganti pelanggan lama yang hilang. Perusahaan tidak berusaha mencari penyebab pelangganpelanggannya meninggalkan mereka (disloyalitas), melainkan lebih fokus pada pencarian pelanggan baru yang sebenarnya lebih banyak memerlukan usaha dan biaya.

Peristiwa disloyalitas pernah terjadi di beberapa negara, misalnya di Jerman pada 2017 yang termuat di handelsblatt.com. Penutupan cabang perbankan untuk mengurangi biaya operasional bank membuat nasabah kecewa yang berujung penutupan akun, karena tidak mendapat manfaat untuk bertahan dalam jangka panjang. Nasabah tersebut beralih ke bank dengan fitur layanan perbankan digital. Bank yang mengalami persoalan ini adalah bank HypoVereinsbank menutup 580 cabang. Deutsche Bank meringkas cabang menjadi 535.5 Disloyalitas juga pernah terjadi pada industri ritel Inggris pada 2018 yang dimuat dalam www.retailgazette.co.uk. Biaya disloyalitas konsumen meningkat hingga $€ 147,2$ miliar. Penyebab peningkatan biaya tersebut dikarenakan perilaku staf $(58,5 \%)$, kualitas dan harga barang. ${ }^{6}$ Persoalan disloyalitas juga pernah dialami Lululemon pada 2013 yang dimuat dalam nbcnews.com. Disloyalitas yang terjadi adalah pelanggan beralih ke merek pesaing. Fenomena tersebut dikarenakan produk celana merek Lulu kurang berkualitas (berbahan terlalu tipis dan mudah tersangkut), perlakuan yang responsif serta inovasi penyelesaian masalah yang tidak dirasakan langsung oleh pelanggan. Perusahaan mendapatkan dampak pada pendapatan dan citra yang dirusak oleh pelanggan. ${ }^{7}$

Faktor yang memengaruhi nasabah untuk disloyalitas disampaikan Saxauer, sebagaimana dikutip oleh Munandar, upaya untuk membangun hubungan dengan nasabah jangka panjang dan kokoh perlu dilakukan Customer Relationship Management yang memperhatikan hubungan dengan pelanggan, pengetahuan tentang pelanggan, proses menjadi pelanggan dan pemanfaatan teknologi untuk pelanggan yang berorientasi ke arah tersebut. Empat faktor tersebut yang dapat menguatkan hubungan dengan nasabah. ${ }^{8} \mathrm{Hal}$ ini sesuai dengan penelitian Anas dan Fadllan yang menyatakan bahwa hubungan berkelanjutan memengaruhi loyalitas nasabah di BMT NU Pragaan Sumenep. ${ }^{9}$ Selain itu, Najmudin melalui penelitiannya menyatakan bahwa menjaga pelayanan, fasilitas dan senantiasa meningkatkannya perlu dilakukan untuk menjaga loyalitas, karena kepuasan pada dasarnya selalu dinamis. Jika dua hal di atas (baca: pelayanan dan fasilitas) diabaikan, maka akan menimbulkan disloyalitas. ${ }^{10}$ Kemudian, dalam penelitian Fikriyah dijelaskan bahwa etika kerja Islami menjadi pertimbangan anggota dalam memutuskan sikap loyalitas. ${ }^{11}$

Hal demikian juga disampaikan dalam penelitian yang dilakukan oleh Nurhayati dan Fatmasaris, bahwa loyalitas dipengaruhi oleh kualitas layanan, kepuasan nasabah dan

\footnotetext{
5"The Problem With Cutting Branches," accessed March 06, 2019, https://www.handelsblatt.com/today/finance/bank-closures-the-problem-with-cutting-branches/

6 "Cost of Customer Disloyal Rises to $£$ 142,2bn," accessed March 06, 2019,
https://www.retailgazette.co.uk/blog/2018/11/cost-consumer-disloyalty-rises-147-2-billion/

7 "Lululemon Complaints Stretch Beyond Quality to Custimerservice," accessed March 06, 2019 https://www.nbcnews.com/businessmain/lululemon-complaints-stretch-beyond-quality-customer-service$\underline{8 \mathrm{C} 11514726}$

8 Munandar, Relationship Marketing, 10.

${ }_{9}^{9}$ Achmad Tarmidzi Anas dan Fadllan Fadllan, "Pengaruh Hubungan Berkelanjutan terhadap Kesetiaan Nasabah di BMT NU Cabang Pragaan Kabupaten Sumenep," IQTISHADIA: Jurnal Ekonomi \& Perbankan Syariah 4, no. 1 (2017): 66-81.

10 Najmudin, “Loyalitas Nasabah Terhadap Bank-Bank Syariah di Yogyakarta,' EFEKTIF Jurnal Bisnis dan Ekonomi, 2011.

11 Fikriyah, "Islamic Work Ethic in Zakat Institution in Indonesia: How Does it Effect Customer Loyalty?." IJCIET,2019.
} 
religiusitas. Sehingga perbankan syariah harus menjaga kualitas layanan yang diberikan kepada nasabah, sehingga menciptakan kepuasan yang berujung pada loyalitas nasabah dan menghindari disloyalitas. ${ }^{12}$ Disebutkan pula dalam penelitian Zikiene dan Lina, faktor yang mendukung beralihnya tingkah laku (baca: loyal menjadi disloyal) yaitu berkaitan dengan harga, ketidaknyamanan, kegagalan layanan inti, kualitas tidak memuaskan, kegagalan pertemuan layanan dan pencarian varietas, berganti tempat tinggal pelanggan serta adanya nilai baru. Sehingga faktor tersebut juga menjadi perhatian kaitannya dengan perubahan tingkah laku nasabah menjadi loyal atau disloyal. ${ }^{13}$

Amin menuturkan bahwa jika setiap agen atau kru mengesampingkan nilai-nilai sosial, apabila lingkungan sosial tidak berpegang pada nilai dan etika maka akan berpengaruh negatif bagi manajemen. Akibatnya bisa terjadi praktik eksploitasi dan komersialisasi jabatan. ${ }^{14}$ Upaya tersebut berfungsi untuk mengenalkan dan menanamkan kepercayaannya pada perusahaan dan didapati nasabah yang loyal. Penelitian yang dilakukan Zakiy menjelaskan bahwa perlakuan agen bank dan produk yang ditawarkan menjadi penentu loyalitas nasabah. Sehingga sikap pegawai bank syariah harus memperdulikan keluhan nasabah, kecewa yang berujung pada disloyalitas tentu menjadi masalah serius bagi bank syariah jika tidak mendapatkan perlakuan atau penyelesaian yang baik. Maka memungkinkan nasabah akan berhenti menggunakan produk dari bank syariah tersebut dan beralih ke perbankan syariah yang lain. ${ }^{15}$

Pengenalan dan penanaman kepercayaan tersebut juga perlu didasari integrasi informasi. Mengingat integrasi informasi sangat vital dalam perbankan syariah. Khususnya dalam pembangunan citra perbankan di masyarakat maupun nasabah. perlunya penyampaian informasi dari instansi tersebut dilakukan melalui komunikasi yang terbagi atas dua jenis: komunikasi verbal yang berupa lisan (dialog AO/FO dengan nasabah) atau tulisan (id card maupun slip transaksi); komunikasi non verbal melalui seragam. Sehingga apabila AO/FO gagal dalam mentransfer informasi mengenai identitas lembaga yang diwakilinya, maka citra lembaga juga turut menjadi taruhan di masyarakat. Sehingga integrasi informasi tersampaikan dengan sempurna dan menghindari terjadinya disintegrasi informasi yang merugikan perbankan syariah tersebut.16 Penelitian Aini dan Wadhan juga menyatakan bahwa strategi bauran pemasaran memengaruhi peningkatan loyalitas nasabah di BPRS Bhakti Sumekar. ${ }^{17}$

Biro Riset Infobank (BirI) melakukan penelitian pada BPRS Secara nasional dengan indikator kinerja keuangan yang berupa Rasio Permodalan, Kualitas Aset, Rentabilitas, Likuiditas, Efisiensi serta Pertumbuhan Dana, Pembiayaan, Modal dan Laba. Berdasarkan penelitian tersebut, BPRS Lantabur memperoleh peringkat ke-5 skala nasional pada kategori BPRS berkinerja keuangan "Sangat Bagus" dengan aset Rp. 100 Miliar - di bawah Rp. 250 Miliar dan menjadi satu-satunya yang berasal dari Jawa Timur dengan perolehan

\footnotetext{
12 Nurhayati, "Peningkatan Loyalitas Nasabah Bank Syariah Melalui Peningkatan Kualitas Layanan dan Kepuasan Nasabah dengan Variabel Religiusitas sebagai Variabel Moderating," Economica Volume VII/Edisi 2, 2016.

13 Zikiene \& Lina, "Research of Factors Influencing Customer Switching Behaviour in Farmer's Market in Lithuania," Research for Rural Development, 2016.

${ }_{14}$ Amin, Menggagas Manajemen Syariah: Teori dan Praktik The Calestial Management, Jakarta: Salemba Empat, $2010,17$.

15 Zakiy, “Pengaruh Kualitas Layanan Terhadap Loyalitas Nasabah Bank Syariah dengan Kepuasan Nasabah,” Jurnal Ekonomi dan Bisnis Islam, 2017.

16 Amin, Menggagas Manajemen Syariah, 166.

17 Aini dan Wadhan, "Pengaruh Strategi Bauran Pemasaran Terhadap Peningkatan Loyalitas Nasabah pada BPRS

Bhakti Sumekar Kantor Cabang Pamekasan," Iqtishadia: Jurnal Ekonomi dan Perbankan Syariah Vol 3 No. 2, 2016.
} 
penghargaan serupa. ${ }^{18}$ BPRS Lantabur mempunyai kantor pusat di Kabupaten. Jombang dan memiliki dua kantor cabang yang berada di Kota Mojokerto dan Kabupaten. Gresik.

"Upaya demikian dilakukan untuk menjangkau pangsa pasar yang lebih luas dalam memenuhi kebutuhan masyarakat. Namun, BPRS Lantabur Tebuireng Kanca Mojokerto memiliki nasabah yang mengurangi bahkan tidak lagi menggunakan produk atau layanan dari BPRS Lantabur Tebuireng Kanca Mojokerto lagi."19

Nasabah disloyal di BPRS Lantabur Tebuireng yang berada di Pasar Prajurit Kulon sebanyak 57 nasabah atau sebesar 16,62\% dari nasabah di Prajurit Kulon.

Berdasarkan uraian di atas, penelitian ini penting dilakukan untuk mengetahui dan mengkaji faktor-faktor yang memengaruhi disloyalitas yang terjadi pada perbankan syariah dalam sektor bank pembiayaan rakyat syariah dengan judul "Analisis Faktor Yang Memengaruhi Disloyalitas Nasabah Perbankan Syariah (Studi Kasus Nasabah BPRS Lantabur Tebuireng di Pasar Prajurit Kulon)."

\section{METODE PENELITIAN}

Pengujian normalitas penelitian ini menggunakan uji Kolmogorov-Smirnov Test yang dinyatakan data normal apabila nilai signifikansi (Sig.) lebih besar dari ( $>$ ) 0,05. Data tidak terdistribusi secara normal jika nilai signifikansi (Sig.) kurang dari $(<)$ 0,05. Pada penelitian ini nilai signifikansi (Sig.) untuk setiap variabel sebagai berikut: Paradigma Keagamaan $(0,303)$; Motivasi Religi $(0,192)$; Etika Bisnis Islam $(0,452)$; Eksploitasi Jabatan $(0,130)$; Harga $(0,130)$; Kualitas $(0,057)$; Nilai Manfaat $(0,431)$; Kepuasan Nasabah $(0,130)$; Pelayanan Efektif $(0,151)$; Fasilitas $(0,511)$; Kegagalan Layanan $(0,315)$; Kenyamanan Sosial $(0,582)$; Peningkatan Kinerja $(0,151)$; Pemanfaatan Teknologi $(0,107)$; Disintegrasi Informasi $(0,709)$; Inovasi $(0,403)$; Ketidaknyamanan Layanan $(0,329)$; dan Kepedulian Sosial $(0,208)$; serta Demografi $(0,724)$. Sesuai dengan data hasil Kolmogorov-Smirnov Test tersebut, diketahui bahwa semua variabel memiliki nilai signifikansi (Sig.) lebih besar dari (>) 0,05. Sehingga data terdistribusi secara normal pada setiap variabel.

Pengujian kelayakan suatu variabel dalam penelitian ini melalui KMO and Bartlett's Test. KMO and Bartlett's Test menyatakan bahwa Jika nilai KMO-MSA (Kaiser-Meyer-Olkin Measure of Sampling Adequacy) lebih besar ( $>$ ) dari 0.50 maka teknik analisis faktor layak digunakan. Hasil KMO and Bartlett's Test pada penelitian ini menghasilkan nilai KMO MSA sebesar 0,760 (lebih besar dari 0.50) serta nilai Bartlett's Test of Sphericity (Sig.) untuk penelitian ini sebesar 0,000 (kurang dari 0,05). Hal ini menjelaskan bahwa teknik analisis faktor dapat digunakan atau relevan dalam penelitian ini.

Anti-image Matrices dalam penelitian ini difungsikan untuk mengetahui dan menentukan variabel yang layak untuk dipakai dalam analisis faktor dengan persyaratan yang harus terpenuhi yaitu nilai $M S A$ lebih besar dari (>) 0,50. Nilai $M S A$ dalam penelitian ini adalah sebagai berikut: Paradigma Keagamaan sebesar 0,651; Motivasi Religi sebesar 0,783; Etika Bisnis Islam sebesar 0,755; Eksploitasi Jabatan sebesar 0,841; Harga sebesar 0,833; Kualitas sebesar 0,688; Nilai Manfaat sebesar 0,699; Kepuasan Nasabah sebesar 0,792; Pelayanan Efektif sebesar 0,656; Fasilitas sebesar 0,813; Kegagalan Layanan sebesar 0,769; Kenyamanan Sosial sebesar 0,776; Peningkatan Kinerja sebesar 0,785; Pemanfaatan Teknologi sebesar 0,728; Disintegrasi Informasi sebesar 0,690; Inovasi sebesar 0,810; Ketidaknyamanan Layanan sebesar 0,780; dan Kepedulian sosial sebesar 0,776; serta Demografi sebesar 0,760. Sehingga melalui hasil di atas dapat diketahui bahwa nilai $M S A$

18 “Ini Dia 63 BPRS Peraih Infobank Sharia Awards 2018,” accessed October 06, 2018.

19 Munawaroh, Qibtiatul. Wawancara July 24, 2018. 
semua variabel yang diteliti dalam penelitian ini memenuhi persyaratan, yaitu lebih besar dari 0.50. Sehingga semua variabel layak untuk dilakukan analisis faktor.

Dalam Principal Component Analysis terdapat dua kriteria analisis, yaitu Communalities dan Eigen Value. Communalities dalam penelitian ini berfungsi untuk mengetahui kemampuan variabel untuk menjelaskan faktor. Variabel dianggap mampu menjelaskan faktor jika nilai extraction pada variabel lebih besar $(>)$ dari 0.50 . sehingga jika nilai extraction kurang dari (<) 0.50 maka variabel tersebut tidak dapat menjelaskan faktor. Nilai Extraction variabel dalam penelitian ini dijelaskan dalam tabel berikut:

Tabel 2.

Communalities

\begin{tabular}{lrr}
\hline \multicolumn{1}{c}{ Variabel } & Initial & Extraction \\
\hline Paradigma Keagamaan & 1,000 & 0,848 \\
Motivasi Keagamaan & 1,000 & 0,457 \\
Etika Bisnis Islam & 1,000 & 0,492 \\
Eksploitasi Jabatan & 1,000 & 0,536 \\
Harga & 1,000 & 0,520 \\
Kualitas & 1,000 & 0,702 \\
Nilai Manfaat & 1,000 & 0,676 \\
Kepuasan Nasabah & 1,000 & 0,627 \\
Pelayanan Efektif & 1,000 & 0,760 \\
Fasilitas & 1,000 & 0,695 \\
Kegagalan Layanan & 1,000 & 0,679 \\
Kenyamanan Sosial & 1,000 & 0,684 \\
Peningkatan Kinerja & 1,000 & 0,710 \\
Pemanfaatan Teknologi & 1,000 & 0,430 \\
Disintegrasi Informasi & 1,000 & 0,742 \\
Inovasi & 1,000 & 0,751 \\
Ketidaknyamanan Layanan & 1,000 & 0,701 \\
Kepedulian Sosial & 1,000 & 0,633 \\
Demografi & 1,000 & 0,472 \\
\hline
\end{tabular}

Berdasarkan tabel di atas, dapat diketahui bahwa variabel yang dapat menjelaskan faktor adalah variabel Paradigma Keagamaan, Eksploitasi Jabatan, Harga, Kualitas, Nilai Manfaat, Kepuasan Nasabah, Pelayanan Efektif, Fasilitas, Kegagalan Layanan, Kenyamanan Sosial, Peningkatan Kinerja, Disintegrasi Informasi, Inovasi, Ketidaknyamanan Layanan, Kepedulian Sosial. Sedangkan yang tidak memenuhi persyaratan dan dinyatakan tidak mampu menjelaskan faktor adalah Motivasi Keagamaan, Etika Bisnis Islam, Pemanfaatan Teknologi dan Demografi.

Eigen Value merupakan jumlah varian yang dijelaskan oleh setiap faktor dan menentukan jumlah faktor yang muncul. Eigen Value ini dapat dilihat dalam total variance explained yang menunjukkan nilai masing masing variabel yang dianalisis. Analisis dalam Total Variance Explained dapat dilakukan melalui dua cara, Initial Eigenvalues yang merupakan analisis untuk menunjukkan faktor terbentuk atau Extraction Sums of Loadings yang berarti menunjukkan jumlah faktor yang dapat terbentuk. Pada penelitian ini menggunakan analisis Initial Eigenvalues pada Total Variance Explained dengan 19 variabel, 
sehingga ada 19 component yang dianalisis. Pada Initial Eigenvalues menunjukkan jumlah variabel sebanyak $19(6,504+1,769+1,486+1,242+1,114+0,998+0,886+0,840+0,739$ $+0,615+0,501+0,446+0,378+0,366+0,329+0,266+0,223+0,170+0,128=19,000)$. Eigenvalues juga menunjukkan jumlah faktor yang terbentuk dengan syarat nilai Eigenvalues harus lebih besar $(>)$ dari 1 . Penelitian ini menunjukkan nilai eigenvalues yang memenuhi persyaratan adalah Component $1(6,504)$ maka menjadi faktor 1 dan mampu menjelaskan $34,230 \%$ varian, Component 2 (1,769) menjadi faktor 2 dan mampu menjelaskan 9,309\% varian, Component $3(1,486)$ menjadi faktor 3 dan mampu menjelaskan 7,822\% varian, Component $4(1,242)$ menjadi faktor 4 dan mampu menjelaskan 6,538\% varian, Component 5 $(1,114)$ menjadi faktor 5 dan mampu menjelaskan $5,866 \%$ varian. Nilai total component 6,7 , $8,9,10,11,12,13,14,15,16,17,18,19$ tidak dihitung karena nilai Eigenvalues dari masingmasing component kurang dari $(<) 1$. Sehingga tidak dapat menjadi sebuah faktor.

Rotasi faktor dalam penelitian ini berfungsi untuk memudahkan interprestasi penentuan variabel suatu faktor. Penelitian ini menggunakan rotasi varimax untuk menentukan struktur faktor. Memastikan suatu variabel tergolong dalam kelompok faktor tertentu dapat ditentukan dengan melihat nilai korelasi terbesar antara variabel dengan faktor (Component) yang telah terbentuk. Melalui pengelompokan tersebut didapatkan akumulasi variabel dalam faktor sebagaimana tabel berikut:

Tabel 3.

Hasil Pengelompokan Variabel dalam Faktor

\begin{tabular}{|c|c|}
\hline Faktor & Variabel \\
\hline 1 & $\begin{array}{lcr}\text { Eksploitasi } & \text { Jabatan, Nilai } & \text { Manfaat, } \\
\text { Peningkatan } & \text { Kinerja, Pemanfaatan } \\
\text { Teknologi, } & \text { Disintegrasi } & \text { Informasi, } \\
\text { Inovasi, Ketidaknyamanan Layanan }\end{array}$ \\
\hline 2 & $\begin{array}{l}\text { Etika Bisnis Islam, Harga Produk, } \\
\text { Pelayanan Efektif, Kenyamanan Sosial, } \\
\text { Demografi }\end{array}$ \\
\hline 3 & $\begin{array}{l}\text { Motivasi Keagamaan, Kualitas Produk, } \\
\text { Kepedulian Sosial }\end{array}$ \\
\hline 4 & Fasilitas, Kegagalan Layanan \\
\hline 5 & Paradigma Keagamaan \\
\hline
\end{tabular}

Faktor hasil dari rotasi memunculkan faktor-faktor dengan tingkat korelasi tinggi yang dikategorikan sebagai faktor yang memengaruhi disloyalitas nasabah perbankan syariah yang terjadi pada nasabah PT. BPRS Lantabur Kanca Mojokerto di Pasar Prajurit Kulon Kota Mojokerto. Setelah mendapati variabel dalam sebuah faktor, dilakukan analisis kelayakan faktor dalam merangkum variabel-variabel yang dianalisis melalui Component Transformation Matrix. Component Transformation Matrix dalam penelitian ini digunakan untuk menunjukkan bahwa pada setiap Component memiliki nilai korelasi lebih dari (>) 0,5 sebagai syarat faktor dapat dinyatakan layak dalam merangkum variabel-variabel yang dianalisis. Pada penelitian ini, Component yang memiliki nilai korelasi lebih dari $(>) 0,5$ adalah Component $1(0,605), 2(0,569)$ dan $5(0,509)$. Sedangkan untuk Component $3(-0,675)$ dan $4(0,227)$ tidak dapat merangkum variabel-variabel yang dianalisis, karena nilai korelasinya kurang dari $(<)$ 0,5. Sehingga dinyatakan bahwa Component 1 sebagai Faktor 1 yang terdiri atas variabel Eksploitasi Jabatan, Nilai Manfaat, Peningkatan Kinerja, Pemanfaatan Teknologi, Disintegrasi Informasi, Inovasi serta Ketidaknyamanan Layanan; 
Component 2 sebagai Faktor 2 yang berisi variabel Etika Bisnis Islam, Harga Produk, Pelayanan Efektif, Kenyamanan Sosial dan Demografi. Kemudian Component 5 sebagai faktor 3 dalam penelitian ini terdiri dari Paradigma Keagamaan. Ketiga faktor tersebut adalah faktor yang memengaruhi disloyalitas nasabah perbankan syariah di PT. BPRS Lantabur Tebuireng di Pasar Prajurit Kulon.

Faktor terbentuk yang berisikan variabel-variabel yang diteliti tersebut kemudian dilakukan penamaan faktor berdasarkan karakteristik yang sesuai dengan variabel-variabel yang dirangkum di dalamnya. Faktor 1 memiliki anggota yang terdiri atas variabel Eksploitasi Jabatan, Nilai Manfaat, Peningkatan Kinerja, Pemanfaatan Teknologi, Disintegrasi Informasi, Inovasi Serta Ketidaknyamanan Layanan. Generalisasi untuk tujuh variabel tersebut menghasilkan kesimpulan bahwa faktor 1 dinamakan sebagai faktor Etika Bisnis. Faktor 2 memiliki anggota yang terdiri atas Etika Bisnis Islam, Harga Produk, Pelayanan Efektif, Kenyamanan Sosial Dan Demografi. Generalisasi untuk empat variabel tersebut dihasilkan kesimpulan bahwa faktor 2 dinamakan sebagai faktor Kepuasan Nasabah. Faktor 3 yang terdiri atas Paradigma Keagamaan. Generalisasi untuk variabel ini adalah faktor 3 dinamakan sebagai faktor Religiusitas.

\section{HASIL DAN PEMBAHASAN Faktor Etika Bisnis}

Penelitian ini mengungkapkan bahwa faktor Etika Bisnis memiliki keterikatan antar indikator sebesar 0,605 dan menjadi faktor terkuat yang memengaruhi disloyalitas nasabah perbankan syariah. Faktor ini memiliki beberapa variabel yang mampu menjelaskan karakteristik faktor yang memengaruhi disloyaliyas nasabah perbankan syariah yang terdiri atas variabel Eksploitasi Jabatan, Nilai Manfaat, Peningkatan Kinerja, Disintegrasi Informasi, Inovasi Dan Ketidaknyaman Layanan. Keseluruhan variabel telah lolos uji kemampuan menjelaskan faktor pada uji Communalities. Sehingga dapat dinyatakan bahwa faktor Etika Bisnis menjadi faktor terkuat yang menyebabkan nasabah BPRS Lantabur Tebuireng menjadi disloyal. Etika Bisnis yang baik mampu menghasilkan jalinan hubungan yang baik sesama manusia, sehingga disloyalitas dapat dihindari. Namun jika Etika Bisnis yang diterapkan tidak diperhatikan, maka nasabah akan menjauhi perusahaan. Etika Bisnis demikian juga dilakukan oleh BPRS Lantabur Tebuireng melalui pegawai maupun produk atau layanan dengan tujuan menjadi pertimbangan positif nasabah BPRS Lantabur Tebuireng di Pasar Prajurit Kulon untuk menentukan tindakan menggunakan produk/jasa serta tidak berhenti menggunakannya. Namun, ketika nasabah menemui pegawai yang mengeksploitasi jabatan selaku pegawai BPRS Lantabur Tebuireng untuk kepentingan pribadi, maka akan memengaruhi sikap nasabah untuk berhenti menggunakan jasa BPRS Lantabur Tebuireng. Sebanyak $47 \%$ responden menyatakan setuju bahwa mereka berhenti menjadi nasabah jika ditemui pegawai BPRS Lantabur melakukan eksploitasi jabatan. Oleh karena itu, profesionalitas dalam kerja diperlukan untuk menghindari disloyalitas nasabah dan menimbulkan loyalitas nasabah. Eksploitasi jabatan memang memiliki dampak buruk terhadap individu maupun perusahaan.

Selain itu, nilai manfaat dari jasa/produk BPRS Lantabur juga menjadi variabel dalam faktor etika bisnis yang memengaruhi nasabah disloyalitas terhadap perusahaan. Sebanyak $33 \%$ responden setuju dan $18 \%$ menyatakan sangat setuju mengenai alasan mereka disloyal juga dikarenakan nilai manfaat tidak didapatkan ketika menggunakan jasa bank syariah. Nilai manfaat sangat diperhatikan oleh nasabah dalam menggunakan jasa bank syariah. Sehingga bank syariah perlu memperhatikan nilai manfaat atas layanan atau jasa yang diberikan. Selanjutnya adalah peningkatan kinerja, inovasi perusahaan atau pegawai turut menjadi penentu nasabah disloyal, serta ketidaknyamanan layanan. Ketidaknyaman layanan 
ditimbulkan akibat kebutuhan nasabah yang tidak mendapat layanan yang tepat. Disintegrasi informasi juga memengaruhi disloyalitas nasabah. Disintegrasi informasi ini dapat membuat kepercayaan nasabah menurun dikarenakan informasi yang diterima dari beberapa pegawai tidak terintegrasi/memiliki perbedaan. Jika kepercayaan nasabah dibiarkan, maka akan menyebabkan penurunan jumlah penggunaan jasa bank syariah dan berujung disloyalitas nasabah.

\section{Faktor Kepuasan Nasabah}

Faktor kepuasan nasabah menjadi faktor terkuat kedua yang memengaruhi disloyalitas nasabah pada BPRS Lantabur Tebuireng di Pasar Prajurit Kulon. Faktor kedua ini memiliki tingkat keterikatan variabel sebesar 0,569 dengan variabel yang terdiri atas harga produk, layanan efektif dan kenyamanan sosial, etika bisnis islam dan demografi. Variabel etika bisnis Islam dan demografi tidak mampu menjelaskan faktor sesuai uji communalities disebabkan nilai extraction $<0,50$. Sehingga yang mampu menjelaskan karakteristik kepuasan nasabah yang memengaruhi disloyalitas nasabah perbankan syariah pada penelitian ini adalah adalah harga, layanan efektif, serta kenyamanan sosial.

Kepuasan nasabah terhadap produk atau layanan yang dilakukan BPRS Lantabur menjadi faktor pendukung nasabah untuk disloyal. Nasabah BPRS Lantabur Tebuireng akan memutuskan berhenti menggunakan jasa perusahaan jika ditemui biaya yang dikeluarkan untuk memperoleh jasa tidak sesuai harapan. Selain itu, layanan yang terlalu rumit dan sulit (tidak efektif) menjadi pertimbangan nasabah BPRS Lantabur untuk berhenti menggunakan jasa perusahaan. Kemudian, kenyamanan sosial nasabah atas perlakuan pegawai ataupun produk BPRS Lantabur juga menjadi alasan nasabah menjadi disloyal.

Penelitian ini menguatkan teori kepuasan pelanggan oleh Munandar yang menyatakan bahwa adanya kesenjangan layanan menjadi penyebab hilangnya pelanggan, terdapat perasaan tidak puas pada produk/jasa yang diberikan perusahaan memicu pelanggan untuk meninggalkan perusahaan..$^{20}$ Dengan demikian, bank syariah harus memberikan pelayanan yang optimal kepada nasabahnya secara adil dan berkelanjutan, sehingga tidak terjadi kesenjangan layanan yang berakibat hilangnya nasabah tersebut. Selain itu, hasil penelitian ini sejalan dengan penelitian yang dilakukan oleh Zakiy yang menyatakan bahwa kualitas produk/jasa serta layanan yang ditawaran menimbulkan reaksi pada tindakan loyalitas/disloyalitas nasabah. Nasabah selaku obyek yang menggunakan jasa/layanan bank syariah tentu memperhatikan kualitas jasa/layanan yang digunakan. ${ }^{21}$ Sehingga apabila nasabah merasa kualitas buruk tanpa adanya perbaikan secara baik oleh perbankan, maka nasabah akan memutuskan untuk menghentikan penggunaan sementara atau bahkan berhenti seterusnya.

Penelitian ini juga menguatkan pernyataan dalam penelitian Najmudin yang menyatakan bahwa menjaga pelayanan dan meningkatkannya mampu meningkatkan loyalitas nasabah, dengan demikian akan menghindari disloyalitas nasabah.22 Sebagai lembaga penyedia jasa keuangan syariah, bank syariah perlu meningkatkan kinerja layanan demi mencapai kepuasan nasabah. Hasil upaya tersebut menjadikan nasabah puas dan tidak akan meninggalkan bank syariah. Penelitian ini juga menguatkan penelitian Hudson dkk yang menyatakan bahwa pelayanan efektif memengaruhi disloyalitas. Nasabah mengharapkan

\footnotetext{
20 Munandar, Relationship Marketing, 77.

21 Zakiy, “Pengaruh Kualitas Layanan Terhadap Loyalitas Nasabah Bank Syariah dengan Kepuasan Nasabah,” Jurnal Ekonomi dan Bisnis Islam, 2017.

${ }^{22}$ Najmudin, “Loyalitas Nasabah Terhadap Bank-Bank Syariah di Yogyakarta,' EFEKTIF Jurnal Bisnis dan Ekonomi, 2011.
} 
pelayanan yang efektif, sehingga efisiensi waktu dan tenaga didapatkan.23 Penelitian ini juga sejalan dengan penelitian yang dilakukan Zikiene dan Lina ${ }^{24}$ yang menyatakan bahwa salah satu faktor pendukung beralihnya tingkah laku dari loyal menjadi disloyal adalah ketidaknyamanan sosial yang ditimbulkan. Oleh karena itu, pegawai bank syariah perlu memberikan perlakuan atau respon yang sopan dan baik sehingga nasabah merasa nyaman dan diperhatikan atau diprioritaskan kebutuhannya. Dengan demikian, nasabah akan terhindar dari disloyalitas serta hubungan dengan perbankan syariah terus berjalan.

\section{Faktor Religiusitas}

Faktor ketiga yang memengaruhi disloyalitas nasabah menurut penelitian ini yaitu Religiusitas. Pada faktor ini terdapat hanya satu indikator yang menjelaskan karakteristik Religiusitas yang dapat memengaruhi disloyalitas nasabah perbankan syariah. Variabel tersebut adalah Paradigma Keagamaan. Paradigma Keagamaan yang dimiliki nasabah BPRS Lantabur Tebuireng di Pasar Prajurit Kulon menjadi indikator penilaian terhadap perusahaan. $57 \%$ responden dalam penelitian ini menyatakan setuju bahwa pertimbangan agama menjadi alasan memilih bank syariah dalam memenuhi kebutuhan financial-nya. Nasabah tersebut cenderung menilai ke-syariah-an atau kesesuaian jasa/layanan BPRS Lantabur Tebuireng dengan paradigma keagamaan yang mereka miliki. Sehingga jika ditemukan ketidaksesuaian dengan ajaran agama mereka, maka mereka menjadi disloyal terhadap perusahaan. Oleh karena itu, Faktor Religiusitas dalam perbankan syariah harus melekat dalam organisasi, jasa maupun interaksi sosialnya. Selain untuk menguatkan citra perusahaan, hal demikian akan mengurangi atau menghindari disloyalitas nasabah. Nasabah menilai bahwa bank syariah adalah sebuah perbankan yang menerapkan nilai-nilai keagamaan di dalamnya. Bukan sekadar label syariah, namun nilai-nilai tersebut diterapkan dalam organisasi.

Faktor Religiusitas yang memengaruhi disloyalitas nasabah dalam penelitian ini menguatkan teori religiusitas dalam kerja. Menurut Amin, bahwa seseorang yang melakukan aktivitas atau pekerjaan berlandaskan keimanan dan motivasi agama, maka cenderung memilih yang halal, menjauhi yang haram. ${ }^{25}$ Selain itu, hasil penelitian ini sejalan dengan penelitian yang dilakukan Nurhayati dan Fatmasaris yang menyatakan bahwa religiusitas menjadi faktor penentu nasabah untuk bertahan menggunakan jasa bank syariah atau memutuskan meninggalkan atau disloyal terhadap perusahaan. ${ }^{26}$

\section{PENUTUP}

Faktor yang memengaruhi disloyalitas nasabah perbankan syariah melalui studi kasus pada nasabah BPRS Lantabur Tebuireng adalah faktor Etika Bisnis yang terbentuk dari variabel peningkatan kinerja, pemanfaatan teknologi, inovasi, nilai manfaat serta eksploitasi jabatan, disintegrasi informasi serta ketidaknyamanan layanan. Faktor etika bisnis menjadi faktor terkuat yang memengaruhi disloyalitas nasabah; faktor terkuat kedua adalah kepuasan nasabah yang terbentuk dari variabel harga, layanan efektif dan kenyamanan sosial; serta faktor ketiga adalah religiusitas yang memiliki variabel pembentuk tunggal, yaitu paradigma keagamaan. nasabah BPRS Lantabur Tebuireng di Pasar Prajurit Kulon menjadi disloyalitas

\footnotetext{
${ }^{23}$ Hudson dkk, "Call Centers: is there an upside to the Dissatisfied Customer Experience?" Journal of Business Strategy Vol 38, 2017.

${ }^{24}$ Zikiene \& Lina, "Research of Factors Influencing Customer Switching Behaviour in Farmer's Market," Research for Rural Development. 2016.

25 Amin, Menggagas Manajemen Syariah, hlm. 114.

${ }^{26}$ Nurhayati, "Peningkatan Loyalitas Nasabah Bank Syariah Melalui Peningkatan Kualitas Layanan dan Kepuasan Nasabah dengan Variabel Religiusitas sebagai Variabel Moderating," Economica Volume VII/Edisi 2, 2016.
} 
karena disebabkan etika bisnis, kepuasan nasabah serta religiusitas. Ketiga faktor tersebut menentukan nasabah terus menggunakan atau berhenti menggunakan jasa/layanan BPRS Lantabur Tebuireng.

\section{DAFTAR PUSTAKA}

Amin, A. Riawan. Menggagas Manajemen Syariah: Teori dan Praktik The Calestial Management. Jakarta: Salemba Empat, 2010.

Aini, Yenny K dan Wadhan. Pengaruh Strategi Bauran Pemasaran Terhadap Peningkatan Loyalitas Nasabah Pada BPRS Bhakti Sumekar Kantor Cabang Pamekasan. Iqtishadia: Jurnal Ekonomi dan Perbankan Syariah Vol. 3 No. 2, 2016.

Anas, Achmad Tarmidzi, dan Fadllan Fadllan. "Pengaruh Hubungan Berkelanjutan terhadap Kesetiaan Nasabah di BMT NU Cabang Pragaan Kabupaten Sumenep." IQTISHADIA: Jurnal Ekonomi \& Perbankan Syariah 4, no. 1 (2017): 66-81.

Bungin, Burhan. Metode Penelitian Kuantitatif. Jakarta: Prenada Media, 2005.

Badan Pusat Statistik Kota Mojokerto. Kota Mojokerto Dalam Angka. Kota Mojokerto: BPS Kota Mojokerto, 2018.

Bank Indonesia. UU No. 21 Tahun 2008 Tentang Perbankan Syariah. Jakarta: Bank Indonesia, 2008.

Baroroh, Ali. Analisis Multivariat dan Time Series dengan SPSS 21. Jakarta: Elex Media Komputindo, 2013.

Bhatnagar, Shakti dkk. "Customer Disloyalitas in retail banking services: attitudinal and behavioural dimensions", Asia-Pacific Journal Administration, 2018.

"Cost of consumer disloyalty rises to $£ 147,2 \mathrm{bn} . "$ Retailgazette.co.uk. diakses 06 Maret 2019, dari https://www.retailgazette.co.uk/blog/2018/11/cost-consumer-disloyalty-rises147-2-billion/.

Departemen Perbankan Syariah OJK. Roadmap Perbankan Syariah Indonesia 2015-2019. Jakarta: OJK, 2014.

Fikriyah, Khusnul dkk. Islamic Work Ethic in Zakat Institution In Indonesia: How Does It Effect Customer Loyalty?. International Journal of Civil Engineering and Technology (IJCIET), 2019.

Hudson, Sarah dkk. "Call Centers: is there an upside to the Dissatisfied Customer Experience?", Journal of Business Strategy Vol. 38 Iss 1 pp. 39-46, 2017.

"Ini Dia 63 BPRS Peraih Infobank Sharia Awards 2018". Infobank.news.com. Diakses 06 Oktober 2018. http://infobanknews.com/ini-dia-63-bprs-peraih-infobank-shariaawards-2018/.

Inayah, Nurul dan Sri Sudiarti. Analisis Keputusan Nasabah Menabung di Bank Syariah, AtTawassuth, Vol. 2 No. 1, 2017: 191-214, 2017.

Ismail, Riswandhi. Pengaruh Kualitas Layanan, Kualitas Produk dan Kepuasan Nasabah Sebagai Prediktor dalam Meningkatkan Loyalitas Nasabah, Jurnal Organisasi dan Manajemen, Volume 10 No. 2 September 2014, 179-196, 2014.

Jones,T.O and Sasser, W.E Jr. "Why satisfied customers defect," Harward Business Review,Vol 73 No. 6 pp. 88-99, 1995.

Kuusik, Andreas dan Urmas Varblane. "How to avoid customer leaving: The case of the Estonian Telecommunication Industry," Baltic Journal of Management Vol. 4 Issue 1 pp. 66-79, 2009.

"Lululemon Complaints Stretch Beyond Quality to Customerservice. " Nbcnews.com. diakses 06 Maret 2019, dari https://www.nbcnews.com/businessmain/lululemoncomplaints-stretch-beyond-quality-customer-service-8C11514726. 
Maulana, Hartomi. Factor Influencing Behaviour to Participate in Islamic Microfinance, International Journal of Islamic and Middle Eastern Finance and Management, 2017.

Munandar, Dadang. Relationship Marketing; Strategi Menciptakan Keunggulan Bersaing. Yogyakarta: Ekuilibria, 2016.

Najmudin, Mohamad. "Loyalitas Nasabah Terhadap Bank-Bank Syariah di Yogyakarta", EFEKTIF Jurnal Bisnis dan Ekonomi Vol 2, No. 2, Desember 2011 148-157, 2011.

Nurhayati, Fatmasaris Sukesti. "Peningkatan Loyalitas Nasabah Bank Syariah Melalui Peningkatan Kualitas Layanan dan Kepuasan Nasabah dengan Variabel Religiusitas Sebagai Variabel Moderating", Economica Volume VII/ Edisi 2, 2016.

Otoritas Jasa Keuangan. Laporan Perkembangan Keuangan Syariah Indonesia. Jakarta: OJK, 2017.

OJK. "Statistik Perbankan Syariah - Juli 2018". Jakarta: Otoritas Jasa Keuangan, 2018.

"Profil Bank Syariah Lantabur Tebuireng”. BPRS Lantabur Tebuireng, diakses 25 Maret 2018. http://bprslantabur.id/profil/.

Rowley, Jenifer dan Jillian Dawes. "Disloyalitas: a closer look at non-loyal," Journal of Consumer Marketing, Vol. 17 No. 6 pp. 538-549, 2000.

Solichun, dkk., Islamic Bank Analysis of Marketing Strategy with Perspective Competitive Advantage Muamalat Bank of Indonesia in Jakarta, International Journal of Business and Management Invention ISSN (online): 2319-8028 Volume 2 Issue 8, 2013.

Sugiyono. Metode Penelitian Pendidikan. Bandung: Penerbit Alfabeta, 2016.

"The Problem with Cutting Branches, A Handelsblatt survey reveals that an increase in branch closures is causing a backlash among customers of Germany's big banks." Handelsblatt.com. diakses $06 \quad$ Maret 2019. https://www.handelsblatt.com/today/finance/bank-closures-the-problem-withcutting-branches/.

Tiro, M. Arif dkk. Analisis Faktor. Makassar: Andira Publisher, 2006.

Ulyah, Fikrotul dan Ririn Susilawati. "Pengaruh Komunikasi Interpersonal Terhadap Citra Perusahaan dan Kinerja Keuangan," Falasifa, Vol. 8 No. 2 September 2017- 291, 2017.

Zakiy, Muhammad. Pengaruh Kualitas Layanan Terhadap Loyalitas Nasabah Bank Syariah dengan Kepuasan Nasabah Sebagai Variabel Intervening, Jurnal Ekonomi dan Bisnis Islam Vol. 3 No. 1, 2017.

Zikiene, Kristina dan Lina Pileliene. Research of Factors Influencing Customer Switching Behaviour in Farmer's Market in Lithuania, Research For Rural Development 2016, Volume 2, 2016. 